\title{
Plant Regeneration through Indirect Somatic Embryogenesis in Coelogyne Cristata Orchid
}

\author{
Aung Htay Naing, Jae Dong Chung, Ki Byung Lim
}

School of Applied Biosciences, College of Agriculture and Life Science, Kyungpook National University, Daegu, Republic of Korea. Email: kblim@knu.ac.kr

Received April $7^{\text {th }}, 2011$; revised May $6^{\text {th }}, 2011$; accepted May $18^{\text {th }}, 2011$.

\begin{abstract}
A newly efficient protocol has been established for high frequency somatic embryogenesis through callus culture of Coelogyne cristata. The best frequency of callusing was obtained from leaf segments (3-5 mm) cultured on the MS medium supplemented with $2 \mathrm{mg} \cdot \mathrm{L}^{-1} 2,4-D$ and $2 \mathrm{mg} \cdot \mathrm{L}^{-1} B$ A combination. A negative effect of coconut water was observed on the callus induction medium. When callus lines No. 4, 6 and 8 induced from leaf segments were sub-cultured separately on $1 / 2$ MS and MS media containing AC $\left(1-3 g \cdot L^{-1}\right)$, formation of somatic embryos was found. However, percentages of embryo formation and the number of embryos per explants were strongly affected by media and callus lines used. The effect of 1/2 MS media is definitely better than MS medium for somatic embryogenesis from the selected lines of leaf derived callus. Among the callus lines, line no. 4 is the best for somatic embryogenesis followed by line no. 6 and 8. The somatic embryos converted into healthy plants with well developed shoots on the same media. The plantlets were transferred to $1 / 2 \mathrm{MS}$ medium containing $1 \mathrm{~g} \cdot \mathrm{L}^{-1}$ AC for plant regeneration until 8 weeks of culture and successfully acclimatized in the greenhouse.
\end{abstract}

Keywords: Callus Formation, Embryo Formation, Leaf Segment, Plant Growth Regulators, Tropical Orchid

\section{Introduction}

Coelogyne cristata which belongs to the family Orchidaceae has high ornamental value as a cut flower. It produces its graceful racemes of white flowers with yellow splotches on the throat, and has a long lasting and fragrant scent. In Myanmar, the pseudobulb of Coelogyne cristata is used in making traditional medicine for dysentery and diarrhea. However, wild orchids including $C$. cristata in Myanmar are nowadays steadily decreasing due to over collection of orchid hunters, shifting cultivation, extension of crop cultivation and urban development, which is causing loss of their natural habitats and is leading to extinction. Thus, it is essential to take measures to conserve their germplasm and to reveal efficient propagation protocols to allow for the continuous large supply of materials for medicine. However, there is no report on plant regeneration through somatic embryogenesis in C. cristata. The process has been induced in tissue cultures of orchids either directly from the epidermal cells of explants [1-3] or indirectly via intervening callus [4].

The phenomenon of somatic embryogenesis via callus is rather rare as success of callus formation in orchids has limitations due to slow growth and a tendency to become necrotic [5,6]. Especially, callus formation from leaf explants of orchids has been and is the rarest even now. Even when callus induction was achieved, the frequency of callusing might have been ultimately low and the callus was difficult to maintain and eventually failed to survive. Even when plant regeneration from callus of orchids was achieved, it usually occurred via protocormlike-bodies PLBs [6-8]. Therefore, success of somatic embryogenesis via callus culture is interesting in plant regeneration of orchids. This study presents optimal concentrations of 2,4-D and BA for callus formation and high formation of somatic embryos from the culture of leaf derived callus in Coelogyne cristata using different kinds of media and $\mathrm{AC}$

\section{Materials and Methods}

Mature capsules of Coelogyne cristata were collected from Mingalardon Orchid Farm in Yangon, Myanmar. The capsules were washed thoroughly under running tap water. Then they were sterilized by immersion in $70 \%$ ethanol for 10 seconds and flamed for a short time. After they were dissected longitudinally, seeds were isolated and sown on Hyponex (HP) basal media for in vitro ger- 
mination for 3 months. The germinated plantlets about $1.0 \mathrm{~cm}$ in height were transferred to Murashige and Skoog (MS) basal media supplemented with NAA 1.0 $\mathrm{mg} \cdot \mathrm{L}^{-1}$ and BA $2.0 \mathrm{mg} \cdot \mathrm{L}^{-1}$ for plant growth. After 2 months of culture, leaves of the in vitro plantlets become the explants source to conduct further experiments.

\subsection{Effect of PGRs and Coconut Water on Callus Induction from Leaf Segments}

Leaf segments of about $3-5 \mathrm{~mm}$ in length were used as explants. For investigations on the effects of coconut water $(5 \% \mathrm{v} / \mathrm{v})(\mathrm{MB}$ cell, Seoul, Korea) and plant growth regulators (PGRs) on callus induction, various combinations of 2,4-dichlorophenoxyacetic acid (2,4-D; 0, 1.0, 2.0 and $3.0 \mathrm{mg} \cdot \mathrm{L}^{-1}$ ) and benzyladenine (BA; 0, 1.0, 2.0 and $3.0 \mathrm{mg} \cdot \mathrm{L}^{-1}$ ) were added to MS basal media. Each experiment consisted of 10 explants with three replications. The culture vessels were placed in dark conditions for 12 weeks and forming calli were recorded.

\subsection{Effect of Media and AC on Somatic Embryogenesis}

To examine the effect of media and AC on somatic embryogenesis, the above leaves derived callus lines [line No. $4(26.7 \%)$, line No. $6(40.0 \%)$, line No. $8(36.7 \%)]$ without $\mathrm{CW}$, which showed better callus formation and originated from the same tissue but cultured on the different media compositions, were chosen. And, each callus line was dissected into 2 - $3 \mathrm{~mm}$ sized callus pieces and cultured on the different kinds of basal media (MS and $1 / 2 \mathrm{MS}$ ) containing $\left(1-3 \mathrm{~g} \cdot \mathrm{L}^{-1}\right)$ activated charcoal (AC). Each experiment consisted of 10 explants with three replications. The culture vessels were placed at room temperature under $16 / 8 \mathrm{hr}$ day/night photoperiod at a 20 - $50 \mu \mathrm{mol} \cdot \mathrm{m}^{-2} \cdot \mathrm{s}^{-1}$ photon flux density. Data were recorded after 8 weeks of culture.

\subsection{Plant Regeneration}

Single plants derived from the above experiments were transferred to half-Murashige and Skoog 1/2 MS basal medium supplemented with $1 \mathrm{~g} \cdot \mathrm{L}^{-1} \mathrm{AC}$ for plant regeneration. Regenerated plants were transplanted and acclimatized in the greenhouse.

For all cultures, percentage of sucrose and agar was 3.0 and $0.8 \%$ respectively. The $\mathrm{pH}$ of medium was adjusted to 5.8 before adding agar. Data were analyzed by DMRT $(P>0.05)$.

\section{Results and Discussion}

Developing somatic embryogenic culture systems with reliable regeneration capacity from ornamental plants is a prerequisite for mass propagation and their genetic improvement. Studies were being intensively made to de- velop a protocol for somatic embryogenesis. The process can be induced in tissue cultures of orchids either directly from the epidermal cells of explants [1-3] or indirectly via intervening callus [4]. In this study, somatic embryogenesis was induced indirectly through callus culture.

In general, formation of callus in orchids is rather difficult due to its slow growth and necrotic tendency, especially, success of callus induction from leaf segments is the rarest. In this study, when leaf segments were cultured on the hormone free medium they became swollen, and followed by initiation of a callus mass was visible from the wound edges of leaf segment after 4 weeks of culture. The calli were granular, whitish to light yellow and comprised of isodiametric cells. Higher frequencies of callus induction from explants were obtained on the basal media supplemented with various concentrations of 2,4-D and BA (Table 1). However, ratios between concentrations of 2,4-D and BA were significantly associated with percentages of survival of explants and callus formation. On the contrary, either the lowest concentration of 2,4-D and the highest concentration of BA or a higher concentration of 2,4-D and lower concentration of BA showed synergistic effects on callus induction from leaf segments. Of the combinations of 2,4-D and BA tested, $2 \mathrm{mg} \cdot \mathrm{L}^{-1} 2,4-\mathrm{D}$ and $2 \mathrm{mg} \cdot \mathrm{L}^{-1} \mathrm{BA}$ were found as optimal concentrations for the best callus induction $(40.0 \%)$. The color of callus induced from each combination was slightly changed from whitish to yellow and most yellow callus showed granular type. However, callus mass obtained from highest concentrations of 3 $\mathrm{mg} \cdot \mathrm{L}^{-1} 2,4-\mathrm{D}$ was reddish yellow in color.

Addition of $\mathrm{CW}$ to the same media containing 2,4-D and BA, frequencies of callusing were relatively low as compared to those on the media devoid of CW. Almost all of the leaf segments died on $\mathrm{CW}$ containing media. However, percentage of callusing was stable on the media containing concentration of $3 \mathrm{mg} \cdot \mathrm{L}^{-1} 2,4-\mathrm{D}$ and 1 $\mathrm{mg} \cdot \mathrm{L}^{-1} \mathrm{BA}$ as devoid of $\mathrm{CW}$.

Recently, combinations of 2,4-D and TDZ have been reported for the callus induction of ornamental plants including some orchid genera, Cymbidium [7], Vanda coerulea [9], Cypripedium formosanum [10]. However, BA alone or in combination with 2,4-D totally inhibited callus induction in Paphiopedilum hybrid [11]. Similarly, [12] mentioned that the combination of 2,4-D and BA could not effectively induce callus from leaf segment in Phalaenopsis. In the present study, combination of 2,4-D and BA has successfully induced callus from leaf segments within a short period of time. However, the presence of $\mathrm{CW}$ inhibited callus induction from leaf segment in this species. A similar result was observed in Phalaenopsis [12]. It is clear that $\mathrm{CW}$ has an inhibitory effect on callus induction from leaf segments of orchids. Ac- 
cording to our findings in this study, exogenous hormones are quite important for callus induction and no effect of CW was observed on callus induction from leaf segments in this species.

According to the results shown in Table 1, the lines (No. 4, 6, 8) showed better callus formation. Thus, plant regeneration through the lines should be critically considered. Although plant regeneration through organogenesis of callus culture has been fully developed in some orchids, efficient protocol for embryogenesis through callus culture of orchids still has been quite limited. Therefore, pieces of callus originating from the above callus lines $(4,6,8)$ without $\mathrm{CW}$ were separately cultured on MS and $1 / 2$ MS basal media supplemented with different concentrations of $\mathrm{AC}\left(1-3 \mathrm{~g} \cdot \mathrm{L}^{-1}\right)$ to ex-

Table 1. Effect of phytohormones on callus induction from leaf segments of Coelogyne cristata after 12 weeks of culture in dark conditions.

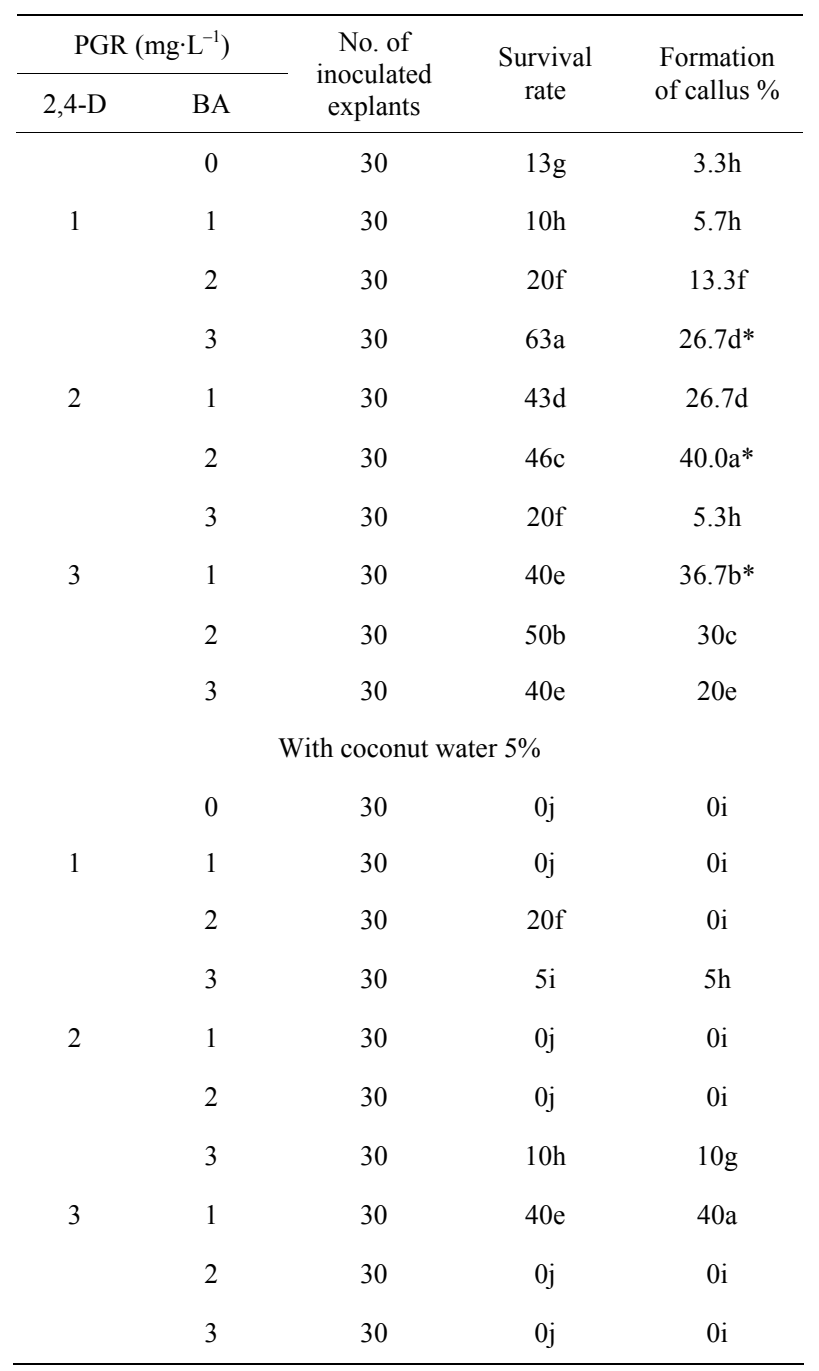

Means within the same letter are not significantly different by DMRT (P > $0.05)$. amine somatic embryogenesis of the callus lines.

Degrees of somatic embryogenesis were totally affected by callus lines and media. In general, explants from all callus lines cultured on 1/2 MS basal media responded with embryo formation well. However, percentages of embryo formation and the number of embryos were distinctly different along with the callus lines used. Line 4 callus responded formation of embryos in all treatments when they were cultured on 1/2 MS medium. However, the highest number of embryos per explants (30.3) was recorded on the media with $2.0 \mathrm{mg} \cdot \mathrm{L}^{-1} \mathrm{AC}$. When line 6 callus was used, the maximum average number of embryos completely decreased (15.0/explant) and the optimum concentration of $\mathrm{AC}$ was varied. Culture of line 8 callus on the same media responded with a lower average number of embryos than that of line 6 . Although the callus lines originated from the same origin, the line 8 attained from the highest concentration of 2,4-D $\left(3 \mathrm{mg} \cdot \mathrm{L}^{-1}\right)$ was the lowest capacity for embryogenesis and also required the highest concentration of $\mathrm{AC}\left(3 \mathrm{~g} \cdot \mathrm{L}^{-1}\right)$ for optimum induction of somatic embryos. It seems that the effect of higher concentration of 2,4-D inhibited positively on somatic embryogenesis of later experiments. Many workers also reported that the higher concentrations of 2,4-D distinctly suppressed somatic embryo formation in Oncidium [1,2] and in Phalaenopsis [13]. The presence of 2,4-D in the culture medium seemed to inhibit somatic embryogenesis in Citrus [14]. Thus, lower concentration of 2,4-D should be used in callus induction to occupy higher somatic embryo formation capacity. As we discussed here, callus obtained from hormone free medium might have the highest somatic embryogenesis capacity as compared to those obtained from 2,4-D containing media.

On MS medium, formation of embryos was rarely observed from line 4 and line 6 calli and formation frequency and number of embryos per callus were extremely low as compared to those on 1/2 MS medium. Different capacities of somatic embryogenesis in callus lines of the same origin were distinctly noticed in each medium. On MS and 1/2 MS media, capacity of embryo formation shows line $4(30 \%, 5.0)>$ line $6(20 \%, 2.0)>$ line $8(0,0)$, and line $4(100 \%, 30.3)>$ line $6(100 \%, 15.0)$ $>$ line $8(70 \%, 12.0)$ (Tables 2,3 and 4$)$, respectively. According to our findings herein, $1 / 2$ MS medium induced a higher number of somatic embryos (12 to 30 per explant) as compared to MS media where the number of embryos was 2 to 4 per explant. The obtained embryos passed through the developmental stages, firstly the embryogenic callus produced localized groups of cells, which differentiated into embryogenic forms on the peripheral region of the cluster old callus, showed induction of rhizogenesis and trichome after 20 days of culture 
Table 2. Effect of different basal media and AC on somatic embryogenesis of callus line 4 obtained from $1 \mathrm{mg} \cdot \mathrm{L}^{-1} 2,4-\mathrm{D}$ and $3 \mathrm{mg} \cdot \mathrm{L}^{-1}$ BA combination.

\begin{tabular}{cccc}
\hline $\begin{array}{c}\text { Basal } \\
\text { medium }\end{array}$ & $\begin{array}{c}\text { Activated } \\
\text { charcoal }\left(\mathrm{g} \cdot \mathrm{L}^{-1}\right)\end{array}$ & $\begin{array}{c}\text { Forming } \\
\text { embryo }(\%)\end{array}$ & $\begin{array}{c}\text { No. of } \\
\text { embryos/explant }\end{array}$ \\
\hline \multirow{4}{*}{$1 / 2 \mathrm{MS}$} & 1.0 & $100 \mathrm{a}$ & $5.0 \mathrm{c}$ \\
& 1.5 & $100 \mathrm{a}$ & $5.6 \mathrm{c}$ \\
& 2.0 & $100 \mathrm{a}$ & $30.3 \mathrm{a}$ \\
& 2.5 & $100 \mathrm{a}$ & $8.0 \mathrm{~b}$ \\
& 3.0 & $100 \mathrm{a}$ & $8.0 \mathrm{~b}$ \\
MS & 1.0 & $0 \mathrm{c}$ & $0 \mathrm{~d}$ \\
& 1.5 & $0 \mathrm{c}$ & $0 \mathrm{~d}$ \\
& 2.0 & $30 \mathrm{~b}$ & $5.0 \mathrm{c}$ \\
& 2.5 & $0 \mathrm{c}$ & $0 \mathrm{~d}$ \\
\hline
\end{tabular}

Means within the same letter are not significantly different by DMRT $(P>$ $0.05)$.

Table 3. Effect of different basal media and AC on somatic embryogenesis of callus line 6 obtained from $2 \mathrm{mg} \cdot \mathrm{L}^{-1} 2,4-\mathrm{D}$ and $2 \mathrm{mg} \cdot \mathrm{L}^{-1}$ BA combination.

\begin{tabular}{cccc}
\hline $\begin{array}{l}\text { Basal } \\
\text { medium }\end{array}$ & $\begin{array}{c}\text { Activated } \\
\text { charcoal }\left(\mathrm{g} \cdot \mathrm{L}^{-1}\right)\end{array}$ & $\begin{array}{c}\text { Forming } \\
\text { embryo }(\%)\end{array}$ & $\begin{array}{c}\text { No. of } \\
\text { embryos/ explant }\end{array}$ \\
\hline \multirow{4}{*}{$1 / 2 \mathrm{MS}$} & 1.0 & $0 \mathrm{~d}$ & $0 \mathrm{~d}$ \\
& 1.5 & $0 \mathrm{~d}$ & $0 \mathrm{~d}$ \\
& 2.0 & $80 \mathrm{~b}$ & $3.3 \mathrm{~b}$ \\
& 2.5 & $100 \mathrm{a}$ & $15.0 \mathrm{a}$ \\
MS & 3.0 & $0 \mathrm{~d}$ & $0 \mathrm{~d}$ \\
& 1.0 & $0 \mathrm{~d}$ & $0 \mathrm{~d}$ \\
& 1.5 & $0 \mathrm{~d}$ & $0 \mathrm{~d}$ \\
& 2.0 & $0 \mathrm{~d}$ & $0 \mathrm{~d}$ \\
& 2.5 & $20 \mathrm{c}$ & $2 \mathrm{c}$ \\
\hline
\end{tabular}

Means within the same letter are not significantly different by DMRT $(P>$ $0.05)$.

Table 4. Effect of different basal media and AC on somatic embryogenesis of callus line 8 obtained from $3 \mathrm{mg} \cdot \mathrm{L}^{-1} 2,4-\mathrm{D}$ and $1 \mathrm{mg} \cdot \mathrm{L}^{-1}$ BA combination.

\begin{tabular}{cccc}
\hline $\begin{array}{c}\text { Basal } \\
\text { medium }\end{array}$ & $\begin{array}{c}\text { Activated } \\
\text { charcoal }\left(\mathrm{g} \cdot \mathrm{L}^{-1}\right)\end{array}$ & $\begin{array}{c}\text { Forming } \\
\text { embryo }(\%)\end{array}$ & $\begin{array}{c}\text { No. of } \\
\text { embryos/explant }\end{array}$ \\
\hline \multirow{4}{*}{$1 / 2 \mathrm{MS}$} & 1.0 & $0 \mathrm{~b}$ & $0 \mathrm{c}$ \\
& 1.5 & $0 \mathrm{~b}$ & $0 \mathrm{c}$ \\
& 2.0 & $0 \mathrm{~b}$ & $0 \mathrm{c}$ \\
& 2.5 & $70 \mathrm{a}$ & $4 \mathrm{~b}$ \\
& 3.0 & $70 \mathrm{a}$ & $13.5 \mathrm{a}$ \\
MS & 1.0 & $0 \mathrm{~b}$ & $0 \mathrm{c}$ \\
& 1.5 & $0 \mathrm{~b}$ & $0 \mathrm{c}$ \\
& 2.0 & $0 \mathrm{~b}$ & $0 \mathrm{c}$ \\
& 2.5 & $0 \mathrm{~b}$ & $0 \mathrm{c}$ \\
& 3.0 & $0 \mathrm{~b}$ & $0 \mathrm{c}$
\end{tabular}

Means within the same letter are not significantly different by DMRT $(P>$ $0.05)$.
(Figure 1(a)) and finally the process subsequently continued leading to formation of somatic embryos (Figure 1(b)). After 10 days of culture, the somatic embryos became mature, green plumules emerged and completely differentiated into individual plants. Roots with clear visible root- cap and root-hairs were observed (Figures 1(c) and (d)).

Addition of higher concentrations of AC to 1/2 MS medium showed even root and embryos formation from the embryogenic clumps. In contrast to lower concentration of $\mathrm{AC}$, formation of roots was much higher than formation of embryos and the roots gradually died. No morphological differences were found among the embryos of callus lines cultured on 1/2 MS medium. However, there was slight morphological variation between embryos obtained from MS and 1/2 MS media. It was found that there was no roots formation from embryogenic callus clump cultured on MS medium containing $\mathrm{AC}$ and obtained embryos seemed slow and had poor growth, and did not differentiate into individual plantlets until 8 weeks of culture. Plants obtained through somatic embryogenesis of leaf derived callus cultured on 1/2 MS media were almost uniform and looked quite healthy.

Recently, AC has been reported on somatic embryogenesis of some plants, Castanea dentata [15], Vitis spp. [16], Myrciaria aureana [17]. However, using AC for somatic embryogenesis in orchids is considerably rare. In this study, AC could effectively stimulate formation of somatic embryos in each line cultured on 1/2 MS media.

\section{Plant Regeneration}

The $1.0 \mathrm{~cm}$ high individual plants from multiple shoot clusters were separated after 8 weeks of culture on above media and transferred to $1 / 2$ MS basal medium supplement with $1 \mathrm{~g} \cdot \mathrm{L}^{-1} \mathrm{AC}$ for rooting and shoot growth. After 2 weeks, formation of roots from each plant cultured on the medium was distinctly observed. They grew faster and became 4-cm-high plants within 8 weeks of culture. Then, these plantlets that bore over 7 roots were transferred to small plastic pots containing moss and bark (2:1) and acclimatized in the greenhouse. Cultural requirements such as watering, temperature control and fertilization were done as necessary.

In conclusion, somatic embryos were indirectly induced from leaf derived callus. Application of the callus was appropriate for somatic embryogenesis in this species. Formation of callus was achieved on MS medium supplemented with 2,4-D and BA combinations. Callus obtained from lower concentration of 2,4-D combination was revealed to have a greater potential for the phenomenon of somatic embryogenesis on $1 / 2 \mathrm{MS}$ medium with $2 \mathrm{mg} \cdot \mathrm{L}^{-1} \mathrm{AC}$. Healthy plants developed through somatic embryogenesis survived well when transplanted 


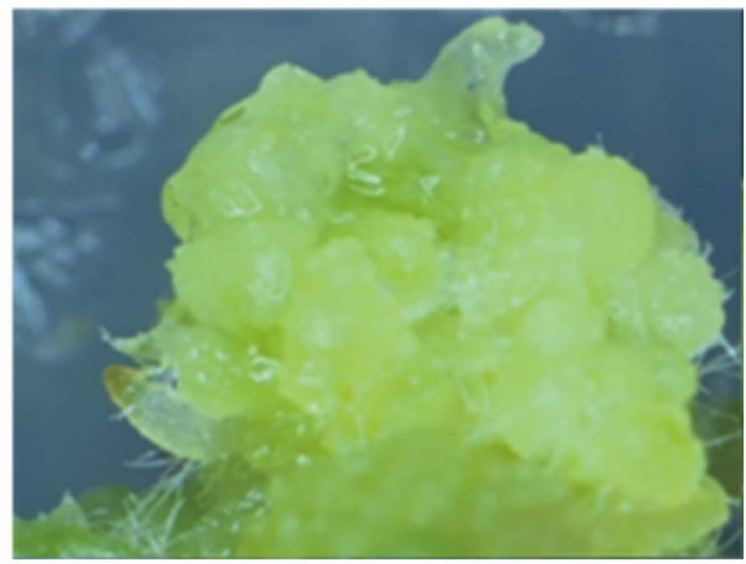

(a)

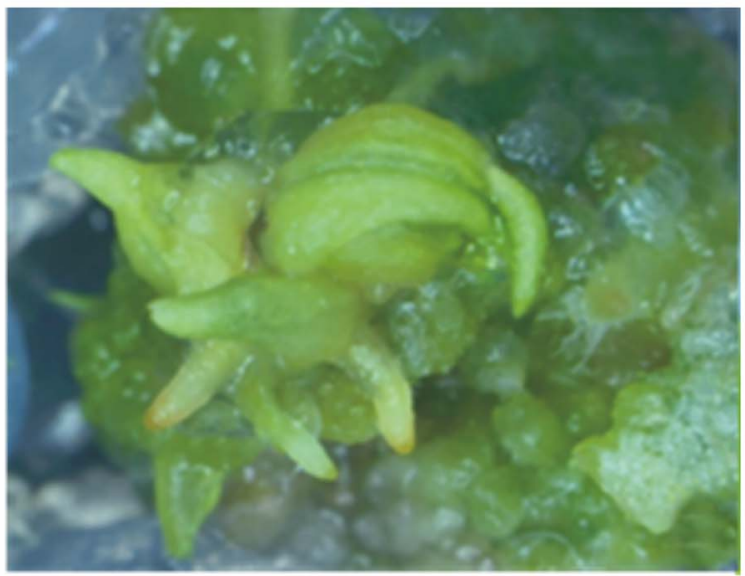

(c)

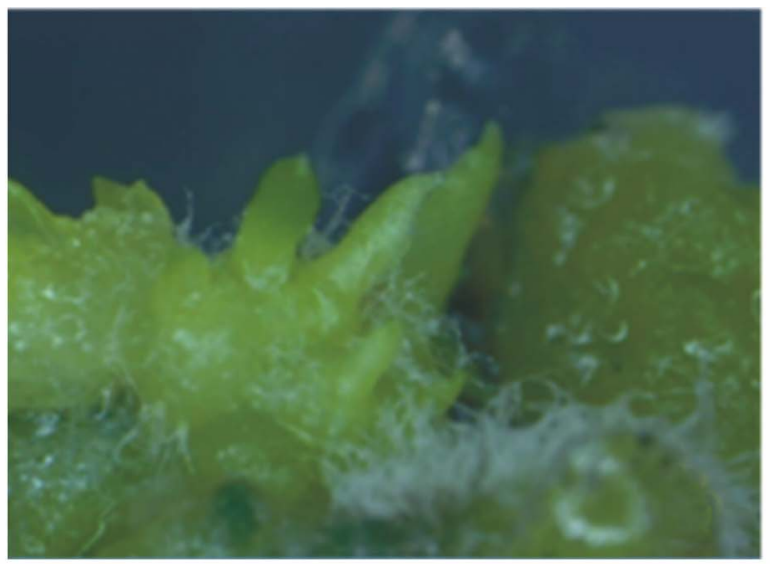

(b)

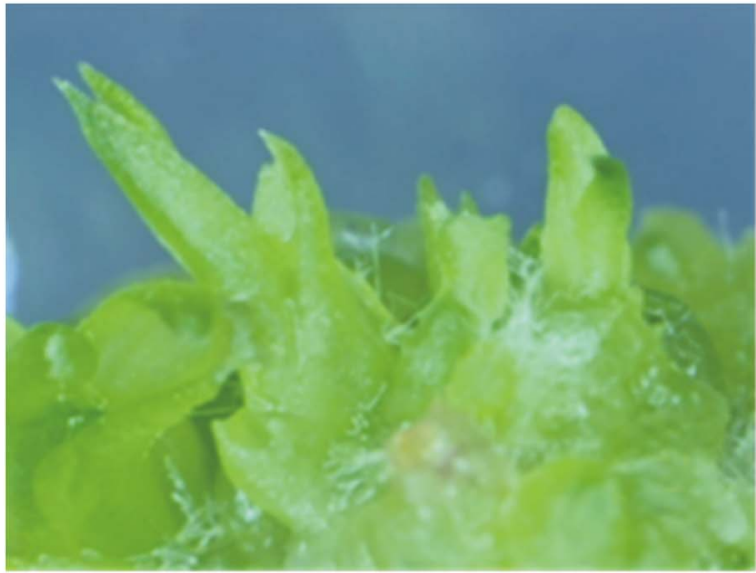

(d)

Figure 1. Plant regeneration through somatic embryogenesis of leaf derived callus. (a) showing of clusters old callus, rhizogenesis and trichomes. (b) formation of somatic embryos. (c) fully developed somatic embryos. (d) conversion of somatic embryos to shoots.

in the greenhouse. This protocol is simple, easy to carry out and can provide a large number of embryos and plants for mass propagation in a short period of time. We expect that this ability will also open up the prospect of using biotechnological approaches for Coelogyne cristata improvement.

\section{Acknowledgements}

The authors acknowledge the financial support of Bio Green 21 Program (code \# 20070301034033), Rural Development Administration, Republic of Korea.

\section{REFERENCES}

[1] J. T. Chen, C. Chang and W. C. Chang, "Direct Somatic Embryogenesis on Leaf Explants of Oncidium Gower Ramsey and Subsequent Plant Regeneration," Plant Cell Report, Vol. 19, No. 2, December 1999, pp. 143-149. doi:10.1007/s002990050724
[2] J. T. Chen and W. C. Chang, "Effects of Auxins and Cytokinins on Direct Somatic Embryogenesis on Leaf Explants of Oncidium 'Gower Ramsey'," Plant Growth Regulation, Vol. 34, No. 2, June 2001, pp. 229-232. doi:10.1023/A:1013304101647

[3] H. H. Chung, J. T. Cheng and W. C. Chang, "Plant Regeneration through Direct Somatic Embryogenesis from Leaf Explants of Dendrobium," Biologia Plantarum, Vol. 51, No. 2, June 2007, pp. 346-350. doi:10.1007/s10535-007-0069-x

[4] J. F. Wu, J. T. Chen and W. C. Chang, "Effects of Auxins and Cytokinins on Embryo Formation from Root-Derived Callus of Oncidium 'Gower Ramsey',, Plant Cell, Tissue and Organ Culture, Vol. 77, No. 1, April 2004, pp. 107 109. doi:10.1023/B:TICU.0000016492.45075.a3

[5] G. B. Kerbauy, "Plant Regeneration of Oncidium Varicosum (Orchidaceae) by Means of Root Tip Culture," Plant Cell Reports, Vol. 3, No. 1, February 1984, pp. 27-29. doi:10.1007/BF00270224

[6] A. Begum, M. Tamaki and S. Kako, "Formation of Pro- 
tocorm-Like-Bodies (PLB) and Shoot Development through in Vitro Culture of Outer Tissue of Cymbidium PLB," Journal of the Japanese Society for Horticultural Science, Vol. 63, No. 3, 1994, pp. 663-673. doi:10.2503/ijshs.63.663

[7] L. V. T. Huana, T. Takamura and M. Tanaka, "Callus Formation and Plant Regeneration from Callus through Somatic Embryo Structures in Cymbidium Orchid," Plant Science, Vol. 166, No. 6, June 2004, pp. 1443-1449. doi:10.1016/j.plantsci.2004.01.023

[8] J. Roy and N. Banerjee, "Induction of Callus and Plant Regeneration from Shoot Tip Explants of Dendrobium Fimbriatum Lindl. var. Oculatum Hk.f," Scientia Horticulturae, Vol. 97, No. 3, February 2003, pp. 333-340. doi:10.1016/S0304-4238(02)00156-5

[9] N. T. Lang and N. T. Hang, "Using Biotechnological Approaches for Vanda Orchid Improvement," Omonrice, Vol. 14, 2006, pp.140-143.

[10] Y. Lee and N. Lee, "Plant Regeneration from Protocorm-Derived Callus of Cypripedium Formosanmun," In Vitro Cellular \& Developmental Biology-Plant, Vol. 39, No. 5, September 2003, pp. 475-479. doi:10.1079/IVP2003450

[11] Y. H. Lin, C. Chang and W. C. Chang, "Plant Regeneration from Callus Culture of a Paphiopedilum Hybrid," Plant Cell, Tissue and Organ Culture, Vol. 62, No. 1, July 2000, pp. 21-25. doi:10.1023/A:1006425214471

[12] Y. Ishii, T. Takamura, M. Goi and M. Tanaka, "Callus Induction and Somatic Embryogenesis of Phalaenopsis,"
Plant Cell Reports, Vol. 17, No. 6-7, April 1998, pp. 446-450. doi:10.1007/s002990050423

[13] H. L. Kuo, J. T. Chen and W. C. Chang, "Efficient Plant Regeneration through Direct Somatic Embryogenesis from Leaf Explants of Phalaenopsis 'Little Steve'," In Vitro Cellular \& Developmental Biology_Plant, Vol. 41, No. 4, July 2005, pp. 453-456. doi:10.1079/IVP2005644

[14] S. Fiore, F. D. Pasquale, F. Carimi and M. Sajeva, "Effect of 2,4-D and 4-CPPU on Somatic Embryogenesis from Stigma and Style Transverse Thin Cell Layers of Citrus," Plant Cell, Tissue and Organ Culture, Vol. 68, No. 1, January 2002, pp. 57-63. doi:10.1023/A:1012944100210

[15] G. M. Andrade and S. A. Merkle, "Enhancement of American Chestnut Somatic Seedling Production," Plant Cell Reports, Vol. 24, No. 6, August 2005, pp. 326-334A. doi:10.1007/s00299-005-0941-0

[16] G. Gambino, P. Ruffa, R. Vallania and I. Gribaudo, "Somatic Embryogenesis from Whole Flowers, Anthers and Ovaries of Grapevine (Vitis spp)," Plant Cell, Tissue and Organ Culture, Vol. 90, No. 1, January 2007, pp. 79-83. doi:10.1007/s11240-007-9256-x

[17] S. Y. Motoike, E. S. Saraiva, M. C. Ventrella, C. V. Silva and L. C. C. Salomao, "Somatic Embryogenesis of Myrciaria Aureana (Brazilian Grape Tree)," Plant Cell, Tissue and Organ Culture, Vol. 89, No. 1, April 2007, pp. 75-81. doi:10.1007/s11240-007-9210-y 